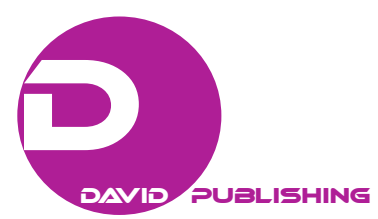

\title{
Characteristics of Supply Logistics: A Research on Mersin Free Zone
}

\author{
Mehmet Miman, Köksal Hazır, Linda Küçük \\ Toros University, Mersin, Turkey \\ Edvar Mum \\ Mersin Free Zone Operator Inc., Mersin, Turkey
}

\begin{abstract}
This study investigates the relationship between demographic characteristics (company type, company ownership, company operating years, and sector) and supply logistics characteristics (source of supplies, average number of suppliers for their products, replenishment frequency for their orders, and relationship with their suppliers) of companies that are operating in Mersin Free Zone along with their supplier selection criteria based on the 36 companies selected through convenience sampling. The finding implies that the relationships of company type - replenishment frequency, company type - relationship among suppliers, and company ownership — source of supplies are significant at the $95 \%$ confidence level. Besides, the most significant three supplier selection criteria are found to be quality, price, and delivery time respectively, while the least important three ones appear to be nationality (foreign/domestic) and the reputation of the supplier respectively.
\end{abstract}

Keywords: supply logistics, supplier selection criteria, Mersin Free Zone, statistics

\section{Introduction}

This study investigates the characteristics of supply logistics of companies that are operating in Mersin Free Zone. Specifically, the effects of company's demographic characteristics (company type, company ownership, company operating years, and sector) on their supply logistics characteristics (source of supplies, average number of suppliers for their products, replenishment frequency for their orders, and relationship with their suppliers) and the criteria that they are used most to select their suppliers are investigated.

Koban and Keser (2013) indicated that supply logistics deals with the fundamental activities that add value to the enterprise and defines supply logistics as all of the activities that regulate the purchasing, planning of uninterrupted entrance of materials from suppliers to producers, warehouses, or retail warehouses, and ensuring the products flow. Supplier selection has a significant place in supply logistics, when it has considered along with its impacts on characteristics of finished products, such as cost, quality, manufacturability, design, and so on (Burt, 1984). Liu and Hai (2005) claimed that an effective supplier selection decision is very important for an organization to be successful in today's competitive environment. Criteria that are used for examination of

Mehmet Miman, Ph.D., assistant professor of industrial engineering, Toros University, Mersin, Turkey.

Köksal Hazır, Ph.D., associate professor of international trade and logistics, Toros University, Mersin, Turkey.

Linda Küçük, instructor/bachelor in logistics, Toros University, Mersin, Turkey.

Edvar Mum, general director/bachelor, Mersin Free Zone Operator Inc., Mersin, Turkey.

Correspondence concerning this article should be addressed to Mehmet Miman, Toros University, 45 Evler Kampüsü, Bahçelievler Mahallesi, 16. Cadde, No. 1/7, 33140 Yenişehir, Mersin, Turkey. 
potential supplier can differ according to companies' needs (Kahraman, Cebeci, \& Ulukan, 2003). According to $\mathrm{Ho}, \mathrm{Xu}$, and Dey (2010), the most popular criteria thought for supplier selection by decision makers are quality, delivery, price/cost, reputation, risk, security, and environment. Dickson (1966) could be regarded as the first one to provide a comprehensive over on the supplier selection criteria. Among the 23 selection criteria he listed, quality, delivery, performance history, guarantee and insurance policy, and production tools' capacity are determined to be the most important criteria in respective order. A literature review on 74 articles over years 1966 through 1990 reveals that net price (in 61 articles) is the most discussed with Dickson's criteria (1996) followed by delivery (in 44 articles) and quality (in 40 articles) (Weber, Current, \& Benton, 1991). There are a variety of studies on supplier evaluation and selection in industrial enterprises in the literature (Weber, 1996; Liu, Ding, \& Lall, 2000; F. T. S. Chan \& H. K. Chan, 2004; Wagner, Ettenson, \& Parrish, 1989; Özer, Miman, \& Taştan, 2015).

The participants of this study are consisting of the 36 selected companies from Mersin Free Zone in Turkey. Free zones are chosen economic regions towards exports where regulations or limitations necessary for foreign trade are partially or completely relaxed to facilitate exportation. Mersin Free Zone, which is the pioneer of today's free zones in Turkey and was established on 3rd of January 1985 according to Free Zones Law (Law No. 3218), has an area of 786,000 $\mathrm{m}^{2}$ and contains 668 companies that employ 4,252 personnel totally (Miman, Hazır, Küçük, \& Mum, 2015). Investigating the characteristics of supply logistics of the companies in Mersin Free Zone with a larger sample, this study can be regarded as the extension of the one conducted by Hazır, Miman, Küçük, and Mum (2015).

The rest of the paper is organized as follows. First, research methodology and model are presented. Later, results and findings of the study are displayed. Finally, it ends up with the conclusions indicating key results, their importance, and potential future studies.

\section{Research Methodology and Model}

This study analyses the effects of company's demographic characteristics (company type, company ownership, company operating years, and sector) on their supply logistics characteristics (source of supplies, average number of suppliers for their products, replenishment frequency for their orders, and relationship with their suppliers) through Chi-square tests based on 36 participating companies selected by ease of sampling. If every cell in cross tabulation, that reflects the relationship, has at least expected number of counts five, Pearson Chi-square tests are used; otherwise Fisher's exact tests are used (Boyacıoğlu \& Güneri, 2006). For all of these hypothesis tests, the significant level is assumed to be $p<0.05$. All of the statistical analyses are conducted through SPSS v.22.0.

To determine the most important criteria for companies operating in Mersin Free Zone, participating companies' general managers/owners are requested rank 20 criteria, listed in Table 1, in terms of their relative importance to them, where the most important criterion is positioned in the first rank, while the least important criterion is positioned in the 20th rank. Some of the responders provided the same rank to several criteria, which implies that the values given by the participants should be interpreted at the importance levels of the criteria, where 1 means that the criterion is the most important, while 20 means that the criterion is the least important.

Thirty-six participating companies have the following demographic (Table 2) and supply logistics (Table 3) characteristics. 
Table 1

Supplier Selection Criteria

\begin{tabular}{llll}
\hline Criterion No. & Criterion description & Criterion No. & Criterion description \\
\hline C1 Technology & Quality & $\mathrm{C} 11$ & Risk \\
C2 & Price & $\mathrm{C} 12$ & Relationships (trust...) \\
C3 & Delivery time & $\mathrm{C} 13$ & Innovativeness \\
C4 & Service & $\mathrm{C} 14$ & Profile/references \\
C5 & Flexibility & $\mathrm{C} 15$ & Proper facility \\
C6 & Production technology & $\mathrm{C} 16$ & Complete deliveries \\
C7 & Technical support & $\mathrm{C} 17$ & Work in accordance with laws \\
C8 & Ease of payment & $\mathrm{C} 18$ & Being a domestic company \\
C9 & Distance & $\mathrm{C} 19$ & Being a foreign company \\
C10 & Financial power & $\mathrm{C} 20$ & Reputation \\
\hline
\end{tabular}

Table 2

Demographic Characteristics of Participating Companies

\begin{tabular}{lllll}
\hline Demographic characteristics & No. & $\%$ & Cumulative percent \\
\hline \multirow{2}{*}{ Type } & Joint-stock & 10 & 27.8 & 27.8 \\
& Limited & 26 & 72.2 & 100.0 \\
\hline \multirow{2}{*}{ Ownership } & Family & 22 & 61.1 & 61.1 \\
& Multi-partner & 14 & 38.9 & 100.0 \\
\hline \multirow{2}{*}{ Operational years } & 8-15 years & 7 & 36.1 & 36.1 \\
& 0-7 years & 16 & 19.4 & 55.6 \\
\hline \multirow{2}{*}{ Sector } & 16 years + & 40 & 44.4 & 100.0 \\
& Textile & 16 & 55.6 & 55.6 \\
\hline
\end{tabular}

Table 3

Supply Logistics Characteristics of Participating Companies

\begin{tabular}{|c|c|c|c|c|}
\hline \multicolumn{2}{|c|}{ Supply logistics characteristics } & \multirow{2}{*}{$\frac{\text { No. }}{4}$} & \multirow{2}{*}{$\begin{array}{l}\% \\
11.1\end{array}$} & \multirow{2}{*}{$\begin{array}{l}\text { Cumulative percent } \\
11.1\end{array}$} \\
\hline & Internal resources & & & \\
\hline \multirow[t]{2}{*}{ Source } & Outsourcing & 6 & 16.7 & 27.8 \\
\hline & Internal and outsourcing & 26 & 72.2 & 100.0 \\
\hline \multirow{2}{*}{$\begin{array}{l}\text { Average number } \\
\text { of suppliers }\end{array}$} & $1-3$ & 11 & 30.6 & 30.6 \\
\hline & Many & 25 & 69.4 & 100.0 \\
\hline \multirow{3}{*}{$\begin{array}{l}\text { Replenishment } \\
\text { frequency }\end{array}$} & Once a week & 14 & 38.9 & 38.9 \\
\hline & Once for every 2-3 weeks & 13 & 36.1 & 75.0 \\
\hline & Once a month/longer period & 9 & 25.0 & 100.0 \\
\hline \multirow{4}{*}{$\begin{array}{l}\text { Relationship with } \\
\text { suppliers }\end{array}$} & Dedicated suppliers & 12 & 33.3 & 33.3 \\
\hline & Contacted (short/long term) suppliers & 11 & 30.6 & 63.9 \\
\hline & Through tender procedure & 6 & 16.7 & 80.6 \\
\hline & Most suitable suppliers each time & 7 & 19.4 & 100.0 \\
\hline
\end{tabular}

Participating companies mostly appear to be a limited (72.2\%), family $(61.1 \%)$, and textile $(55.56 \%)$ company with operational years $0-15$ years $(55.6 \%)$. 
Participating companies mostly appear to use both internal resources and outsourcing (72.2\%), have many suppliers $(69.4 \%)$, have replenishment frequency less than a month $(75.0 \%)$, and work with either dedicated suppliers $(33.3 \%)$ or contract based $(30.6 \%)$.

\section{Results and Analysis}

Chi-square test results conducted to figure out the significant relationships between company's demographic and supply logistics characteristics are shown in Table 4 with corresponding significance values ( $p$-values) of the tests.

Table 4

Relationship Between Demographic and Supply Logistics Characteristics: p-values

\begin{tabular}{|c|c|c|c|c|}
\hline \multirow[b]{2}{*}{ Demographic factor } & \multicolumn{4}{|c|}{ Supply logistics characteristics } \\
\hline & Source & Average \# of suppliers & Replenishment frequency & $\begin{array}{l}\text { Relationship between } \\
\text { suppliers }\end{array}$ \\
\hline Type & $1.000^{\mathrm{a}}$ & $0.454^{\mathrm{a}}$ & $0.049^{\mathrm{a}^{*}}$ & $0.042^{\mathrm{a}^{*}}$ \\
\hline Ownership & $0.005^{\mathrm{a}^{* *}}$ & $0.716^{\mathrm{a}}$ & $0.753^{\mathrm{a}}$ & $0.066^{\mathrm{a}}$ \\
\hline Operational years & $0.120^{\mathrm{a}}$ & $0.514^{\mathrm{a}}$ & $0.685^{\mathrm{a}}$ & $0.178^{\mathrm{a}}$ \\
\hline Sector & $1.000^{\mathrm{a}}$ & $0.718^{\mathrm{a}}$ & $0.256^{\mathrm{a}}$ & $0.051^{\mathrm{a}}$ \\
\hline
\end{tabular}

According to Table 4, among the relationships between company's demographic and supply logistics characteristics: Company type - replenishment frequency, company type-relationship between suppliers, and company ownership - source of supplies are found to be significant $(p<0.05)$. It is also noteworthy that company's operational years and sector do not affect any of its supply logistics characteristics investigated in this study. The details of significant relationships are presented in Tables 5, 6, and 7 respectively.

Table 5

Company Type $\times$ Replenishment Frequency Cross Tabulation

\begin{tabular}{|c|c|c|c|c|c|c|}
\hline \multirow{2}{*}{\multicolumn{2}{|c|}{ Demographic characteristics }} & & \multicolumn{3}{|c|}{ Replenishment frequency } & \multirow[b]{2}{*}{ Total } \\
\hline & & & Once a week & $\begin{array}{l}\text { Once for every } \\
2-3 \text { weeks }\end{array}$ & $\begin{array}{l}\text { Once a month/longer } \\
\text { period }\end{array}$ & \\
\hline \multirow{4}{*}{$\begin{array}{l}\text { Company } \\
\text { type }\end{array}$} & \multirow{2}{*}{ Joint-stock } & Count & 4 & 1 & 5 & 10 \\
\hline & & $\%$ & $40.0 \%$ & $10.0 \%$ & $50.0 \%$ & $100.0 \%$ \\
\hline & \multirow{2}{*}{ Limited } & Count & 10 & 12 & 4 & 26 \\
\hline & & $\%$ & $38.5 \%$ & $46.2 \%$ & $15.4 \%$ & $100.0 \%$ \\
\hline \multirow{2}{*}{ Total } & & Count & 14 & 13 & 9 & 36 \\
\hline & & $\%$ & $38.9 \%$ & $36.1 \%$ & $25.0 \%$ & $100.0 \%$ \\
\hline
\end{tabular}

Table 5 indicates that limited companies have more often replenishments for their supplies.

Table 6 reflects that joint-stock companies mainly have formal relationships with their suppliers in forms of either contract $(40.0 \%)$ or tender $(40.0 \%)$, while limited companies have mainly dedicated suppliers for them $(38.5 \%)$.

According to Table 7, the vast majority of family companies obtain their supplies through both internal resources and outsourcing (90.9\%), multi-partner businesses more uniformly obtain their supplies through only internal resources $(21.4 \%)$, outsourcing (35.7\%), or both internal resources and outsourcing $(42.9 \%)$. 
Table 6

Company Type $\times$ Relationship With Suppliers Cross Tabulation

\begin{tabular}{|c|c|c|c|c|c|c|c|}
\hline \multirow{2}{*}{\multicolumn{2}{|c|}{ Demographic characteristics }} & & \multicolumn{4}{|c|}{ Relationship with suppliers } & \multirow[b]{2}{*}{ Total } \\
\hline & & & $\begin{array}{l}\text { Dedicated } \\
\text { suppliers }\end{array}$ & $\begin{array}{l}\text { Contracted } \\
\text { suppliers }\end{array}$ & $\begin{array}{l}\text { Through tender } \\
\text { procedure }\end{array}$ & $\begin{array}{l}\text { Most suitable } \\
\text { suppliers }\end{array}$ & \\
\hline \multirow{4}{*}{ Company type } & \multirow{2}{*}{ Joint-stock } & Count & 2 & 4 & 4 & 0 & 10 \\
\hline & & $\%$ & $20.0 \%$ & $40.0 \%$ & $40.0 \%$ & $0.0 \%$ & $100.0 \%$ \\
\hline & \multirow{2}{*}{ Limited } & Count & 10 & 7 & 2 & 7 & 26 \\
\hline & & $\%$ & $38.5 \%$ & $26.9 \%$ & $7.7 \%$ & $26.9 \%$ & $100.0 \%$ \\
\hline \multirow{2}{*}{ Total } & & Count & 12 & 11 & 6 & 7 & 36 \\
\hline & & $\%$ & $33.3 \%$ & $30.6 \%$ & $16.7 \%$ & $19.4 \%$ & $100.0 \%$ \\
\hline
\end{tabular}

Table 7

Company Ownership $\times$ Source of Supplies Cross Tabulation

\begin{tabular}{|c|c|c|c|c|c|c|}
\hline \multirow{2}{*}{\multicolumn{3}{|c|}{ Demographic characteristics }} & \multicolumn{3}{|c|}{ Source of supplies } & \multirow{2}{*}{ Total } \\
\hline & & & Internal resources & Outsourcing & Internal and outsourcing & \\
\hline \multirow{4}{*}{$\begin{array}{l}\text { Company } \\
\text { ownership }\end{array}$} & \multirow{2}{*}{ Family } & Count & 1 & 1 & 20 & 22 \\
\hline & & $\%$ & $4.5 \%$ & $4.5 \%$ & $90.9 \%$ & $100.0 \%$ \\
\hline & \multirow{2}{*}{$\begin{array}{l}\text { Multi } \\
\text { partner }\end{array}$} & Count & 3 & 5 & 6 & 14 \\
\hline & & $\%$ & $21.4 \%$ & $35.7 \%$ & $42.9 \%$ & $100.0 \%$ \\
\hline \multirow{2}{*}{ Total } & & Count & 4 & 6 & 26 & 36 \\
\hline & & $\%$ & $11.1 \%$ & $16.7 \%$ & $72.2 \%$ & $100.0 \%$ \\
\hline
\end{tabular}

Table 8

Rank Distribution of Supplier Selection Criteria

\begin{tabular}{|c|c|c|c|c|c|c|c|c|c|c|c|c|c|c|c|c|c|c|c|c|}
\hline \multirow{2}{*}{ Rank } & \multicolumn{20}{|c|}{ Criteria } \\
\hline & $\mathrm{C} 1$ & $\mathrm{C} 2$ & $\mathrm{C} 3$ & $\mathrm{C} 4$ & $\mathrm{C} 5$ & $\mathrm{C} 6$ & $\mathrm{C} 7$ & $\mathrm{C} 8$ & C9 & $\mathrm{C} 10$ & $\mathrm{C} 11$ & $\mathrm{C} 12$ & $\mathrm{C} 13$ & $\mathrm{C} 14$ & $\mathrm{C} 15$ & $\mathrm{C} 16$ & $\mathrm{C} 17$ & C18 & C19 & $\mathrm{C} 20$ \\
\hline 1 & 25 & 14 & 13 & 7 & 6 & 8 & 6 & 10 & 2 & 8 & 9 & 7 & 4 & 5 & 6 & 9 & 14 & - & - & 2 \\
\hline 2 & 6 & 11 & 2 & 4 & 3 & 1 & 2 & 3 & 6 & - & 2 & 3 & 2 & 3 & 3 & 3 & 3 & 2 & 2 & 3 \\
\hline 3 & 1 & 6 & 10 & - & 2 & 1 & - & 1 & - & - & 1 & 2 & - & 1 & - & 1 & - & - & - & 1 \\
\hline 4 & 1 & - & 6 & 10 & 1 & - & 1 & 1 & - & - & 2 & - & 1 & - & - & - & - & - & - & - \\
\hline 5 & - & 1 & 1 & 4 & 6 & 1 & 3 & 2 & 2 & 4 & 3 & - & 1 & - & 1 & 2 & - & 1 & 1 & 3 \\
\hline 6 & 1 & - & 1 & - & 4 & 6 & 1 & 2 & 1 & - & - & - & 2 & 1 & - & - & 2 & - & 1 & - \\
\hline 7 & - & 1 & - & - & 1 & 3 & 7 & 1 & 2 & 1 & - & - & 1 & 2 & - & 1 & - & - & - & 1 \\
\hline 8 & - & - & - & 2 & 2 & 2 & - & 5 & 1 & - & - & 3 & - & 1 & 4 & 1 & - & - & - & - \\
\hline 9 & - & - & 1 & - & 2 & 1 & 1 & 1 & 5 & - & 1 & 1 & 2 & - & 1 & 2 & 2 & 1 & - & - \\
\hline 10 & - & - & - & - & - & 1 & - & 1 & 1 & 6 & 3 & - & 4 & 4 & - & 1 & 3 & 1 & 1 & 1 \\
\hline 11 & - & - & - & - & - & 1 & 1 & - & 1 & 4 & 5 & 1 & 2 & 1 & - & - & - & 3 & - & 1 \\
\hline 12 & - & - & - & - & - & - & 1 & 1 & 2 & - & 1 & 5 & 1 & 4 & 1 & - & - & 1 & 1 & 2 \\
\hline 13 & - & - & - & - & - & 2 & 1 & - & 1 & 1 & 1 & 1 & 6 & 1 & 4 & 2 & - & - & - & 1 \\
\hline 14 & - & - & - & - & - & 3 & - & 3 & - & 2 & - & 1 & - & 5 & - & 3 & - & 2 & - & - \\
\hline 15 & - & - & - & 2 & 1 & - & 3 & - & - & 1 & - & - & 1 & 2 & 6 & - & 1 & - & - & 2 \\
\hline 16 & - & - & - & 1 & - & 1 & 1 & - & 1 & 2 & - & 1 & 2 & - & 2 & 5 & 2 & 1 & 1 & - \\
\hline 17 & - & - & - & - & 1 & - & 1 & - & 2 & - & 2 & 2 & 1 & - & 1 & - & 6 & 3 & 1 & 1 \\
\hline 18 & - & - & 1 & - & - & - & 2 & - & - & 2 & 1 & - & - & - & 2 & - & - & 8 & 2 & 2 \\
\hline 19 & - & - & - & - & 1 & - & - & - & 2 & - & - & 3 & - & - & - & 2 & - & 1 & 6 & 5 \\
\hline 20 & - & 1 & - & 1 & 2 & 2 & 1 & - & 2 & - & - & 2 & 1 & 1 & 1 & - & - & 5 & 13 & 5 \\
\hline$\overline{\bar{X}}$ & 1.4 & 2.5 & 3.1 & 5.0 & 6.5 & 7.5 & 8.2 & 5.3 & 9.1 & 8.4 & 6.7 & 9.2 & 9.3 & 8.8 & 9.9 & 8.0 & 6.9 & 14.8 & 16.5 & 12.3 \\
\hline
\end{tabular}


The relative importance of criteria (presented in Table 1) in selection of suppliers by companies in Mersin Free Zone is depicted in Table 8. According to it, while the most three important criteria appear to be $\mathrm{C} 1$ (quality, with average rank $\bar{X}=1.4$ ), C2 (price, with average rank $\bar{X}=2.5$ ), and C3 (delivery time, with average rank $\bar{X}=3.1$ ) respectively; the least three important criteria are found to be $\mathrm{C} 19$ (being a foreign company, with average rank $\bar{X}=16.5$ ), $\mathrm{C} 18$ (being a domestic company, with average rank $\bar{X}=14.8$ ), and C20 (reputation, with average rank $\bar{X}=12.3$ ) respectively.

\section{Conclusions}

This study investigates the supply chain logistics of the companies in Mersin Free Zone, which is one of the most significant economic regions in the southern part of the Turkey based on the 36 companies selected from the region via convenience sampling.

The results imply that the company type affects their replenishment frequencies from suppliers and their relationships with them. In detail, joint-stock companies have less frequent deliveries from their suppliers with which they have more formal relationships form of contracts and tenders. In addition, company's ownership type is found to have a significant relation with their source of supplies. Particularly, while the vast majority of family companies obtain their supplies from both internal resources and outsourcing, the multi-partner companies obtain more uniformly their supplies from internal resources, outsourcing, and both internal resources and outsourcing. Moreover, when the relative importance of supplier selection criteria is investigated, it is revealed that quality, price, and delivery time are the most significant three criteria in respective order, while the nationality (foreign/domestic) of the suppliers and reputation of them are the least three significant criteria.

As a pioneer and exploratory study on supply logistics characteristics of the companies in Mersin Free Zone, the findings of this study can be helpful for related elements of supply chains who are interested in making business with companies in Mersin Free Zone in Turkey. The study can be expended in a variety of ways. First of all, the findings of the study can be verified by a use of a greater sample size. Moreover, the effects of demographic and supply logistics characteristics of companies on relative importance of their supplier selection criteria can be investigated. Lastly, all of these studies can be conducted for other free zones in Turkey to obtain greater insights on supply logistics characteristics in free zones as well as comparative results related to free zones.

\section{References}

Boyacıŏlu, H., \& Güneri, P. (2006). Sağlık araştırmalarında kullanılan temel istatistiksel yöntemler. Hacetepe Dişhekimliği Dergisi, 30(3), 33-39.

Burt, D. N. (1984). Proactive procurement. Englewood Clifs, NJ: Prentice Hall.

Chan, F. T. S., \& Chan, H. K. (2004). Development of the supplier selection model-A case study in the advanced technology industry. Journal of Engineering Manufacture, 218(12), 1807-1824.

Dickson, G. W. (1966). An analysis of vendor selection systems and decisions. Journal of Purchasing, 2(1), 5-17.

Hazır, K., Miman, M., Küçük, L., \& Mum, E. (2015). Firmaların tedarik ve dağıtım lojistiği eğilimleri. Proceedings from IV Ulusal Lojistik ve Tedarik Zinciri Kongresi, 21-23 Mayıs, Gümüşhane.

Ho, W., Xu, X., \& Dey, P. K. (2010). Multi-criteria decision making approaches for supplier evaluation and selection: A literature review. European Journal of Operational Research, 202(1), 16-24.

Kahraman, C., Cebeci, U., \& Ulukan, Z. (2003). Multi-criteria supplier selection using fuzzy AHP. Logistics Information Management, 16(6), 382-394.

Koban, E., \& Keser, H. Y. (2013). Dış ticarette lojistik. Bursa: Ekin Basım Yayın Dağıtım. 
Liu, F. H. F., \& Hai, H. L. (2005). The voting analytic hierarchy process method for selecting supplier. International Journal of Production Economics, 97(3), 308-317.

Liu, J., Ding, F. H., \& Lall, V. (2000). Using data envelopment analysis to compare suppliers for supplier selection and performance improvement. Supply Chain Management: An International Journal, 5(3), 143-150.

Miman, M., Hazır, K., Küçük, L., \& Mum, E. (2015). Energy efficiency analysis: Mersin Free Trade Zone example. Proceedings from XIII International Logistics Supply Chain Congress, 22-23 October, İstanbul.

Özer, S., Miman, M., \& Taştan, M. B. (2015). TR62 bölgesinde faaliyet gösteren gıda şirketlerinin tedarikçi seçimi yöntemleri. Proceedings from IV Ulusal Lojistik ve Tedarik Zinciri Kongresi, 21-23 Mayıs, Gümüşhane.

Wagner, J., Ettenson, R., \& Parrish, J. (1989). Vendor selection among retail buyers: An analysis by merchandise division. Journal of Retailing, 65(1), 58-79.

Weber, C. A. (1996). Data envelopment analysis approach to measuring vendor performance. Supply Chain Management, 1(1), 28-39.

Weber, C. A., Current, J. R., \& Benton, W. C. (1991). Vendor selection criteria and methods. European Journal of Operational Research, 50, 2-18. 